\title{
NATURAL-SCIENTIFIC APPROACHES TO HEALTH PROMOTIONAL ACTIVITIES FORMING IN RUSSIAN EDUCATIONAL ESTABLISHMENTS
}

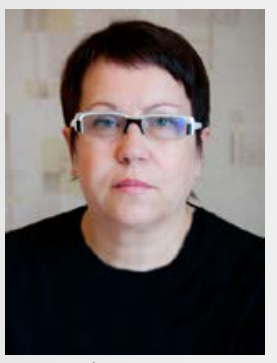

First author:

D. Shibkova

Workplace: The South-Ural State Humanities and Pedagogical University, Chelyabinsk, Russia Chief research worker of the chief research laboratory «Biological systems adaptation to natural and external environmental factors», Federal State Budgetary Educational Institution of Higher Education

Further authors: 0. Kolomietc Workplace: The Ural State University of Physical Culture, Chelyabinsk, Russia E-mail:kolomiec_0@mail.ru

\section{E. Kiss-Tóth}

University of Miskolc Faculty of Healthcare, Hungary E-mail: ekdekan@unimiskolc.hu

\section{A. Rucska}

University of Miskolc Faculty of Healthcare, Hungary E-mail: efkrucsi@unimiskolc.hu

J. Plachy (levelezó szerző és szerkesztőséggel kapcsolattartó)

University of Miskolc Faculty of Heathcare, Hungary E-mail: efkplachy@unimiskolc.hu

\section{Természettudományos megközelítések az egészségfejlesztő tevékenységekben az oroszországi nevelési intézményekben}

\begin{abstract}
Introduction: The analysis of medical-biological and psychological-pedagogical literature is very important on solving the problem and look for further health promotional activities for develop the health status of growing generation.
\end{abstract}

Aim: The aim was to examine the changing in students' health status in two primary school in Chelyabinsk, Russia. It was analysed, that "Who is responsible for schoolchildren's state of health?" and "What can we have to do if the health situation doesn't really improve?".

Results: Children were classified to four health categories (in 2010, 2012, and 2014) according to the Order of the Ministry of Health of the Russian Federation No. 60 of 1995. The differences were determined by Student's t-test $(p<.05)$. The results show increase of schoolchildren, having $\mathrm{III}^{\mathrm{rd}}$ health group to finishing school.

Summary: The best influencing factors in students' health status is the family and school staff. The healthy lifestyle taking account to the specific character of current situation.

Key words: primary school, students' health status,

\section{INTRODUCTION}

The analysis of medical-biological and psychological-pedagogical literature is very important on solving the problem and look for further health promotional activities for develop the health status of growing generation. Secondarily, our aim was to improve the actual health promotional activities forming in educational institutions in Chelyabinsk, Russia.

Nowadays, the students' health preservation problem in modern school is being solved through traditional approaches realization - for example the physiological and the hygienic demands standardization towards educational process organization), as well as by health preservation technologies implementation. These technologies are aimed at forming special conditions within educational environment and innovations into teaching staff working methods. Priority in health promotional technologies choice belongs to municipal educational establishments.

The health promotional technologies, what were used in educational establishments, forms and methods analysis were carried out by the Ministry of Education and Science of the Russian Federation and the Developmental Physiology Institute of the Russian Academy of Education earlier. The examination was carried out in following ways: preliminary monitoring, risk factors, existing at school, and recommended ways for their elimination, health promotional activities factors and methods, organizational approaches to solving the problem (Bezrukikh, and Son'kina, 2002). Some incompliance in general educational institutions activities was found out.

According to the facts, more municipal educational establishments, which meets the fact of the Federal Law «On Education», use preliminary monitoring before programs for health preservation and promotion development. These institutions prove the used working forms and methods meeting demands of certain educational establishments scientifically; conduct real educational loading analysis and its comparison with routine and educational programs; carry out sanitary and hygienic conditions analysis for educational environment (Pankova et.al, 2016).

Health promotion is a scientific measure- 
ment method, which is used by schools for observe students' physical or mental health, educational quality and competence levels' increase. Health promotional education is realized on modern person-centered paradigm principles of students' education and growing population.

During performing their professional functions, teachers are responsible either prevention, or students' mental, physical and spiritual health development. Adequate institutions guarantee the increase in students' psychological, physiological and morphological status, according to their age- and gender expectation. All of this represents a guarantee for schoolchildren's successful adaptation in certain educational establishments.

The ability to adapt to changing environmental conditions is «one of the most significant peculiarities of living person's forms» (Shmalhausen, 1946), moreover, these organisms search for optimal and most stable health state actively. It is reflected in adaptation to new conditions of its existence. The basis of adaptive process to educational activities consists of some mechanisms, starting their action as a reaction on educational environment adequate or destabilizing factors working.

The aim of the study was to examine the changes in students' health status in two primary school in Chelyabinsk, Russia over four years. It was analysed, that "Who is responsible for schoolchildren's state of health?" and "What can we have to do if the health situation doesn't really improve?".

\section{METHODS}

Sample was chosen in Chelyabinsk, because it is confirmed by All-Russian population medical examinations. There are negative tendencies in children's, especially schoolchildren at the beginning of studying (aged 7 -9), during subject training start (aged $10-11$ ), before finishing school (aged 15-17) in their health state.

During school medical data analysis special attention is paid to medical examination results before entering school, especially to specialized doctors' examination, a child's physical development evaluation and his her placing into a definite health group. Our analysis results of students' health state at the beginning of studying, received during surveillance studying of children, studying at different educational establishments.
The examination have been executed in two region in Chelyabinsk: Central and Tractor Plant District. Students were analysed in three times in 2010, 2012, 2014. Children were classified to four health category according to the Order of the Ministry of Health of the Russian Federation No. 60 of 1995. The differences were determined by Student's t-test $(\mathrm{p}<.05)$.

\section{RESULTS}

Students' health status are presented in Table 1. The results analysis shows, that during beginning of studying from $80 \%$ to $90 \%$ of children have some health lesions. Educational programs are designed for apparently healthy children, so, only a school teacher can adapt educational process for a certain child. Moreover it is his her direct workplace role.

Table 1.: Students' placement according to health groups (\%) during studying beginning (data, received in Chelyabinsk)

\begin{tabular}{|c|c|c|c|c|c|}
\hline \multicolumn{1}{|c|}{$\begin{array}{c}\text { District } \\
\text { students }\end{array}$} & $\begin{array}{c}\text { Ist health } \\
\text { group }\end{array}$ & $\begin{array}{c}\text { Ilnd } \\
\text { health } \\
\text { group }\end{array}$ & $\begin{array}{c}\text { Illrd } \\
\text { health } \\
\text { group }\end{array}$ & $\begin{array}{c}\text { IVth } \\
\text { health } \\
\text { group }\end{array}$ \\
\hline $\begin{array}{c}\text { Tzentralny (Central) } \\
\begin{array}{c}\text { Traktorozavodskoy } \\
\text { (Tractor plant }\end{array}\end{array}$ & 158 & $10,10 \%$ & $59,50 \%$ & $29,70 \%$ & $0,60 \%$ \\
\hline $\begin{array}{c}\text { district) } \\
\text { Total: }\end{array}$ & 104 & $16,50 \%$ & $54,90 \%$ & $27,20 \%$ & $1 \%$ \\
\hline
\end{tabular}

But still, innovative pedagogical technologies largescale implementation is not always conducted on the basis of preliminary physiological and hygienical investigations. Meanwhile, children's adaptive processes during innovative educational technologies realization 
are characterised by significant decrease in organism's functional abilities. The evidence of it is demonstrated in publications, where facts on innovative methods negative influence over schoolchildren's functional state and health are presented. It should be admitted, that the true cause for the decrease in schoolchildren's organs functional status, which is caused either by innovational technologies, or schoolchildren's total loading composing of parents' wish to see their child successful in all activities (learning, sport, artistic - aesthetic and so on), or lack of healthy lifestyle in the family.

It is evident, that intensive loading influence over students' organisms under the conditions of permanent growth and development goes beyond the limits of reserve abilities for health promotion. In connection, schools' status, as an establishment for bringing-up physically and mentally healthy citizens. Forming or restitution students' healthy lifestyle is an important task. But the problem resides in the fact, that its solution demands using adequate control means and presence of relevant criteria for morphofunctional and psychophysiological presence state of schoolchildren's organisms' evaluation at different ontogenetic developmental stages.

Harmonization of «education» - «health» system, is, certainly a perspective trend for educational quality increase. Studying educational process conditions and individual psychological and physiological peculiarities of students must be performed during all the period of school studying. The case monitoring for health groups placement changing (from students, aged 7-8 till aged 16-17) results are provided below (Table 2). The results show increase of schoolchildren, having $\mathrm{III}^{\text {rd }}$ health group to finishing school.

Table 2: The examined municipal educational establishments' students' placement to health groups over 10 studying years, (\%) $(\mathrm{n}=102)$ (Yakubovskaya I. A.) health, social well-being and adequately organized educational activities characteristics. Students' physical development delay denotes necessity of finding factors, influencing the process negatively and looking for correction activities ways.

\section{CONCLUSION}

Knowledge of the typological peculiarities of students' higher nervous acivities, defining individual functional peculiarities during studying and bringing-up is compulsory for a teacher. These functional peculiarities are: taking into account age peculiarities of attention and memory mechanisms forming, age and sex peculiarities of analyzer systems development and so on.

Understanding the connection between students' health and their educational process by teachers-practitioners and scientists has become the cause of increase the investigations number, devoted to health promotional technologies working-out and their effectiveness evaluation, and also students' adaptation to educational conditions perfection. Physiological hygienical and psychophysiological research works have persuaded teachers and education system leaders that it is necessary to take special measures for schoolchildren's health preservation and promotion. The most perspective researches in this sphere are these, using complex approach.

At the modern stage of educational system development the most important issue is conjoint medical and psychological care for a child in educational process, as well as early recognition of abnormalities to organize the health-improving and prophylactic measures effectively.

In the National Educational doctrine of the Russian Federation (up to 2025) it is stated, that health promotion must become an integral part of every educational model. On that basis, we can acknowledge, that today the children's right to health preservation and promotion in an educational establishment is an obligatory condition for educational quality increase.

One of the issues of health promotion problems investigations is working-out a quality management and medical-psychological-pedagogical monitoring models under the conditions of educational system electronic communication development.

During such activities much attention is paid to the program of electronic communication development implementation on the level of educational process management (collecting, storing, analyzing and using information); united assistance service, including psychologists, social care teachers, health care professionals and PE teachers organization. The aim of such «assistance service» is to organize system research, providing students with pedagogical support, and teachers - with comfort labor conditions.

Under this approach students' development assistance 
represents a technology of providing complex qualified support for a student at different educational stages, including psychological, medical and biological, social physical and pedagogical components. In this connection the assistance on the whole and its separate items of students' development in educational process has polyfunctional character.

We view the united intraschool assistant service as an effective integration and cooperation form of all educational process parties (students, school authorities, form masters and tutors, subject teachers, social care teachers, educational psychologists, health care professionals, supplementary education teachers, facilitators) to increase educational quality and students' development on the basis of their health promotion, educational establishment health care environment harmonization.

Effective use of conditions, educational establishments are having, is possible only during stable systematic work of teaching staff, families and state in health promotional activities management.

Biological approach to human health problem views organism as a multilevel system, where structural and functional shifts beyond «reaction norm» at one of levels are compensated at others, thanks to evolutionally fixed universal mechanisms of self-regulation. It is an adaptive mechanism, providing homeostasis and possibility of an organism existing with greater or smaller expenses under the conditions of constant spatial-temporal changes. Not every shift of some physical development or functional state characteristics from «average-community» statistic norm can be viewed as developmental or functional disorder: sometimes such a shift can be due to individual developmental heterochronism and biological age delay from real one. It often can be seen not only in primary school students and teenagers, but also in upper-form students. Every organism in every ontogenesis periods has got its own physiological norm. Longitudinal comparison of quantitative and qualitative characteristics of examined persons' different organism systems' functional state allows finding their shifts from the organism functions age dynamics changing, coinciding with community sample (Tkachenko, 2001).

One of the integral organisms' structural - functional system components artificial regulation leads to quantitative and qualitative changes of intra - and extra systematic connections. New connections, being informational signals carriers, cause homeostatic parameters destabilization, aimed at new level of the most adequate organism state in real existing conditions search. The found shifts from the average age - sex norm are not absolute, they reflect increased characteristics level. They can show adaptive potential realization within particular conditions of vital activity.

The adaptive process basis includes organism's nonspecific resistance mechanisms, activating as a reaction to destabilizing factors of natural and social environment. These demonstrations of organism responsiveness can be viewed as individual health measure (Sidorov and Sovershaeva, 2001). In modern conception, World Health Organization, views the necessity of scientifically grounded technologies for health forming working-out and implementation as one of top-priority problems. They have to be based on individual health forming mechanisms knowledge.

So, two most important issues on the discussed problem have found solution. Issue \# 1: Who is responsible for schoolchildren's state of health? The answer can be presented in some variants: a state, a family, a school, a person! Or a family, a school, a state, a person! Issue \# 2: What can we have to do if the health situation doesn't really improve? The answer can be: The healthy lifestyle taking account to the specific character of current situation.

\section{REFERENCES:}

Methodological recommendations «Health promotional technologies in general academic schools: analysis methodology, forms, methods, application experience» / Under the editorship of M. M. Bezrukikh, V. D. Son'kina. - M.: Triada-farm. $-2002 .-114 \mathrm{p}$.

Pankova N. B. Pathophysiological analysis of educational environment risk factors influence over students' organism functional state: donozological research: Abstract of a thesis ... Doctor of Biological Sciences / Pankova Natalya Borisovna (03.00.13;14.00.16). - Moscow, 2009. $-47 \mathrm{p}$.

Shibkova D. Z. Morphofunctional and psychophysiological peculiarities of schoolchildren's adaptation to educational activities [Text]: monograph / D. Z. Shibkova, P. A. Bajguzhin, M. V.

Semenova, A. A. Shibkov. - Chelyabinsk: South-Ural State Humanities and Pedagogical University printing house, 2016. $-380 \mathrm{p}$.

Shmalhausen I. I. Evolutional factors (stabilizing selection theory) / I. I. Shmalhausen. - M.; L.: Academy of Sciences of the USSR printing house, 1946. - $315 \mathrm{p}$.

Sidorov P. I. Quated on: Physiological basics of human health / P. I. Sidorov, S. L. Sovershaeva; under the editorship of B. I. Tkachenko. - Sankt-Petersburg; Archangelsk. 2001. - 708 p.

Smirnova Yu. V. School health promotional activities: systematic approach // Education quality (Kachestvo obrazovanija), 2008. - \# 6. - P. 51-54.

Tkachenko B. I. Physiological basics of human health / under the editorship of B. I. Tkachenko. - Sankt-Petersburg; Archangelsk. 2001.- 708 p.

Yakubovskaya I. A. Gender peculiarities of morphofunctional development and psychophysiological profile of Chelyabinsk students: Candidate of Biological Sciences... thesis / I. A. Yakubovskaya. - Chelyabinsk, 2008 - 135 p. 